\title{
A luta armada em Moçambique e a construção de uma nação
}

\author{
Samuel Correa Duarte \\ César Alessandro Sagrillo Figueiredo
}

Resumo: Este artigo visa examinar a tentativa de construção de uma nova nação através da Frente de Libertação Moçambicana (FRELIMO), negando o velho passado colonial português e construindo o que se convencionou chamar de o "homem novo moçambicano". Constatouse que, a despeito das tentativas de se erigir uma nova sociedade, Moçambique falhou por razões naturais e de política interna e internacional, principalmente pela contraofensiva da Resistência Nacional de Moçambique (RENAMO).

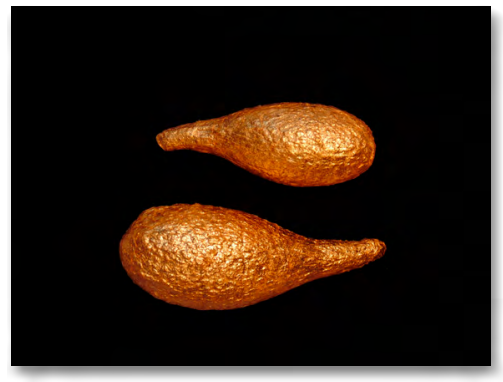

Palavras-chave: Moçambique.

FRELIMO. Luta armada. Estado-Nação.

\section{$\overline{\text { Samuel Correa Duarte }}$}

Graduado em Ciências Sociais pela Universidade Federal de Minas Gerais (UFMG), mestre em Ciência Política pela UFMG e estudante de doutorado do Programa de Pós-Graduação em Sociologia da Universidade Estadual do Ceará (UECE). Professor de Ciências Sociais da Universidade Federal do Maranhão (UFMA).

E-mail: samuelcorrea.duarte@gmail.com

\section{César Alessandro Sagrillo FIgUEIREDO}

Graduado em Ciências Sociais, mestre em Ciência Política e doutor em Ciência Política pela Universidade Federal do Rio Grande do Sul (UFRGS). Professor de Ciências Sociais da Universidade Federal de Tocantins (UFT).

E-mail: cesarpolitika@gmail.com

\section{Armed struggle in Mozambique and nation- building}

\begin{abstract}
This article aims to examine the attempt to build a new nation through the Mozambican Liberation Front (FRELIMO), denying the old Portuguese colonial past and building what was conventionally called the "new Mozambican man". It was found that, despite attempts to build a new society, Mozambique, for natural and internal and international political reasons, failed, mainly due to the counteroffensive of the National Resistance of Mozambique (RENAMO).
\end{abstract}

Keywords: Mozambique. FRELIMO. Armed struggle. Nation-State.

\footnotetext{
RECEBIDO: $13 / 02 / 2020$

APROVADO: $11 / 04 / 2020$
} 


\section{Introdução}

O processo de descolonização da África no século XX foi fruto de diferentes formas de lutas empreendidas pelo povo africano, com o intuito de efetivar um processo de libertação nacional contra os países imperialistas que os subjugavam política, cultural e economicamente há séculos. O presente artigo visa o estudo do processo de independência de Moçambique, ocorrido em 1975, através da luta capitaneada pela Frente de Libertação de Moçambique (FRELIMO), que iniciou suas ações em 1962 e que procurou engendrar uma nova forma de vida social e política em Moçambique, após sua independência de Portugal.

Portanto, o artigo possui como objetivo principal examinar como desenvolveu-se a luta armada em Moçambique e como foi a contribuição da FRELIMO na construção do novo Estado-nação. A fim de se poder estudar esse longo percurso de tempo, com diversas condicionantes que foram engendradas na luta, cumpre, consequentemente, refinar o artigo com os seguintes objetivos secundários, quais sejam: 1) identificar o pensamento político do qual a FRELIMO era tributária, assim como a figura dos seus principais porta-vozes; 2) examinar o processo de gênese da luta armada em Moçambique e a sua vitória política; após o sucesso da FRELIMO formatando o binômio partido-estado, 3) verificar como esta moldura política procurou elaborar uma nova forma de Estado-nação e construir o homem novo moçambicano.

Para efeitos metodológicos, este artigo é um trabalho qualitativo, pois visa uma reconstituição histórica dos elementos mais importantes da luta moçambicana, através de referenciais bibliográficos significativas. Ainda, a fim de situar o processo revolucionário em Moçambique, primeiramente, deve-se realçar qual era a lógica colonial e qual o papel que Portugal exercia em Moçambique, demonstrando, por conseguinte, como se processou esse quadro histórico. Para tanto, torna-se de fundamental importância proceder à contextualização histórica e geográfica do universo de pesquisa escolhido. 


\section{Contexto histórico e construção do pensamento de libertação nacional}

Moçambique situa-se no sudeste da África e possui uma superfície de $799.380 \mathrm{Km}^{2}$, banhado pelo Oceano Índico e fronteiriço a Tanzânia, Malawi, Zâmbia, Zimbabwe, Suazilândia e África do Sul. Possui 11 províncias e sua capital é Maputo. Moçambique foi inicialmente colonizado pelos portugueses, no advento das grandes navegações do século XV e, no decorrer do processo colonial, tornou-se um entreposto do comércio de pessoas escravizadas na rota ultramarina portuguesa, constituindo uma colônia de exploração.

Mamigonian (2010), ao tratar da história de vida de José Majojo e Francisco Moçambique, ambos marinheiros que atuavam nas rotas atlânticas no período do tráfico negreiro, destaca o modo como a empresa da escravidão permeava toda a estrutura econômica, social e política de Moçambique, no período colonial, bem como o concurso do Império Britânico, interessado na formação de mercados com mão de obra livre e assalariada, para consumir os bens gerados em sua recente industrialização. Esse aspecto foi fundamental para que a abolição da escravidão pudesse ser atingida - da construção do consenso em torno da ilegalidade da escravidão e seu subproduto, o tráfico negreiro, iria emergir uma categoria de africanos livres e sua subsequente expansão por meio da luta.

Pereira (2019) defende que o processo de ocupação lusitana do território moçambicano e de exploração da população nativa gerou um ciclo de migração forçada para centros urbanos e zonas de mineração. A "racialização" das relações no empreendimento colonial se deu pela força das armas e a letra da lei, esta última configurada em legislações que classificavam a população local e restringiam seus direitos fundamentais. Desse processo, emergiram duas categorias básicas: os assimilados, que abandonaram os costumes nativos para adotar o comportamento e o estilo de vida do colonizador; e os indígenas, que continuavam a viver segundo as tradições a que estavam habituados. A esses últimos foi atribuído a pouca inclinação natural ao trabalho, de modo que a coação se tornava necessária - assim, o trabalho, além de gerar riqueza 
material, também proveria dignidade e civilização aos indígenas. A partir da dominância lusitana em Moçambique, seria exportada para aquela região a ideia moderna de Estado-nação, implicando a homogeneização e a padronização dos hábitos e costumes, com vistas à criação de um povo unificado para um Estado dotado de traços culturais e limites territoriais definidos.

Foi somente com a conferência de Berlim, em 1885, que houve a deliberação de que as potências só poderiam reivindicar as suas colônias para si, se tivessem uma efetiva ocupação do território. Nesse momento, o poderio português se assentou definitivamente em Moçambique. Assim sendo, a partir deste período, pode-se verificar a presença mais significativa dos portugueses no território moçambicano e a sua designação como uma colônia de povoamento. Esta situação, como era de se esperar, acarretou vários constrangimentos e diferentes formas de exploração da população natural da região, considerada nativa.

A ocupação colonial do território moçambicano desencadeou a formação de novas identidades, ora superpostas, ora em conflito às identidades tribais pré-existentes. Para que a estrutura social derivada do escravismo fosse mantida, foi preciso à elite colonial manter o argumento "racialista" que sustentava a escravidão, ainda que esta tenha sido abolida na letra da lei. Assim, brancos e negros continuariam a coabitar a mesma nação, mas em extratos sociais e redutos espaciais diferenciados - o habitat da civilização branca e o gueto da selvageria negra. Entre esses dois segmentos, havia um restrito trânsito de africanos que se identificavam com os valores e o modo de vida do colonizador, na esperança de que a condição negra dentro do sistema escravista pudesse ser mitigada pela adesão aos valores europeus (THOMAZ, 2012).

Quanto a Portugal, durante um grande período do século XX, o país fora dirigido pela rígida ditadura de Salazar, que ascendeu ao poder em 1933. Em 1968, Salazar se viu afastado do governo português por motivos de saúde, mas ainda manteve a sua influência política através de seu sucessor, Marcelo Caetano. Caetano continuou com o modelo de opressão salazarista sobre a população portuguesa da metrópole, bem como sobre as suas colônias ultramarinas. Para conseguir os seus intentos, o governo português 
contava com sua polícia política, a temível Polícia Internacional e de Defesa do Estado (PIDE), que o auxiliava com mãos de ferro na sua linha ditatorial: prendendo, torturando e oprimindo os seus possíveis adversários políticos.

No tocante à Moçambique, no século XX, este era um país com desenvolvimento econômico relativo e sendo eminentemente agrário. Destaca-se ainda que a colônia moçambicana mantinha uma grande diversidade étnica e não contava com uma unidade lingüística, possuindo vários dialetos. Portanto, tais condicionantes mobilizavam a sua caracterização como uma sociedade tradicional, formada por diferentes tribos e, consequentemente, possuidora de diferentes linhagens e chefes tribais. Deve-se realçar que, mesmo com a opressão portuguesa, essas tribos mantinham-se com muita luta, estruturadas dentro da sua própria cultura e sendo relativamente respeitadas.

Frisa-se que a sociedade moçambicana, no período inicial do processo de libertação, era dividida nas seguintes categorias: brancos descendentes de portugueses, negros assimilados e negros considerados como indígenas ou nativos. Realça-se, contudo, que as coerções sofridas pelos negros naturais ou assimilados não se diferenciavam substantivamente, fato este que gerou, ao longo do século XX, um desejo muito forte de luta pela libertação nacional (MONDLANE, 1995). Embora o século XX tenha sido palco de inúmeras transformações, ganhando a denominação de era dos extremos (HOBSBAWN, 2008), Portugal parecia cristalizado em suas velhas estruturas sociais tradicionais, petrificado ainda mais pela cruel e imóvel ditadura salazarista. No período de Salazar, ocorreu o fim de Segunda Guerra Mundial, bem como a divisão do mundo entre os blocos de países socialistas e capitalistas, assim como o início do processo de descolonização da África inglesa e francesa. Portugal, porém, continuava inerte.

Também, neste ínterim, começou a ser gestada a construção de um novo pensamento político pelos próprios africanos, cujo intuito era politizar e fomentar um futuro movimento de libertação. Pode-se demarca-lo de acordo com os seguintes fatos e eventos:1) primeiramente, em 1945, realizou-se o V Congresso Pan-africano, em Manchester, com a participação de delegados africanos, no 
qual foram alinhadas as diretrizes de um programa de ação para a independência e a criação de uma organização para atuar pela independência da África Colonial (RIBEIRO, 2003); 2) posteriormente, em 1957, criou-se o Movimento Anti-Colonial (MAC), em Paris, por Amilcar Cabral e outros expoentes da luta nacionalista (FRANCO, 2009).

Quanto às lutas especificas das colônias portuguesas, pode-se pautar o movimento nacionalista nos seguintes marcos: 1) em 1960, o MAC foi alargado na II Conferência dos Povos Africanos, dando origem à Frente Revolucionária Africana para a Independência das Colônias Portuguesas (FRAIN); 2) houve a Conferência das Organizações Nacionalistas das Colônias Portuguesas (CONCP), agrupando os movimentos de libertação da Guiné e de Cabo Verde (PAIGC), Angola (MPLA), Moçambique (UDENAMO) e São Tomé (CLST). Esta II Conferência dos Povos Africanos realizou-se em 1961, passando a representar um centro de unidade entre os movimentos de libertação das províncias portuguesas (FRANCO, 2009).

Pode-se dizer que uma das figuras mais eminentes deste processo de formação do pensamento nacionalista é o guineense Amilcar Cabral, que se destacou como o grande ideólogo da libertação das colônias portuguesas, influenciando muito o processo de gestação da luta armada em Moçambique. De acordo com as suas próprias palavras:

Para nós, o fundamento da libertação nacional, sejam quais forem às formulações adotadas no plano jurídico internacional, reside no direito inalienável de cada povo a ter a sua própria história e o objetivo da libertação nacional é a reconquista desse direito usurpado pelo imperialismo, isto é, a libertação do processo de desenvolvimento das forças produtivas nacionais. (...) o aspecto principal da luta de libertação nacional é a luta contra o que se convencionou chamar de neocolonialismo (...) vemos que o fenômeno da libertação nacional corresponde necessariamente a uma revolução (CABRAL apud COMITINI, 1980, p. 34).

Torna-se importante, ainda, salientar que a crítica de Cabral enfatizava os seguintes aspectos acerca do neocolonialismo: a) destruição parcial, em geral acompanhada da fixação mais ou 
menos volumosa de uma população exótica; e b) conservação aparente, condicionada pela confinação da sociedade autóctone a áreas ou reservas próprias e geralmente desprovidas de possibilidades de vida, acompanhada da implantação massiva da população exótica (COMITINI, 1980). Portanto, a crítica de Cabral era uma fórmula perfeita para o processo de libertação nacional que almejavam os africanos, uma vez que começavam decididamente a se organizar para se desprenderem de suas metrópoles. Igualmente, destaca-se que, além da figura emblemática de Cabral, também o movimento nacionalista contou com a presença do moçambicano Eduardo Mondlane, professor universitário nos Estados Unidos e, posteriormente, funcionário das Nações Unidas, que acabou tornando-se o principal dirigente e mentor da Frente de Libertação de Moçambique (FRELIMO).

Peixoto e Meneses (2013) entendem que a vitória do empreendimento anticolonial da FRELIMO se deu às expensas da polissemia do processo de produção de uma identidade, pois a necessidade do movimento de criar uma expressão nacional também implicou o silenciamento dos grupos minoritários e divergentes, tanto dentro quanto fora do movimento. A memória nacional homogênea continha certa unilateralidade, quando contrastada com a miríade de sentidos e valores que permeavam um tecido social em ebulição revolucionária.

As origens da FRELIMO remontam às negociações entre a União Democrática Nacional de Moçambique (Udenamo), a Mozambique African National Union (Manu) e a União Nacional Africana de Moçambique Independente (Unami), com vistas a integrar esforços na luta ante a empresa colonial. Desde o I Congresso da FRELIMO (1962), se tornou evidente que o movimento deveria se contrapor a toda forma de colonialismo (o inimigo externo) e às ameaças contra a unidade popular moçambicana (o inimigo interno). Em outras palavras:

O significado essencial do I Congresso é duplo: o I Congresso estabeleceu uma plataforma justa, capaz de unir todos os patriotas moçambicanos; o I Congresso fixou como objetivo central da FRELIMO, a libertação da Pátria e determinou a estratégica e a tática para atingirmos esses objetivos (...). O I 
Congresso definiu o papel fundamental da unidade no processo de libertação nacional; ela provou que a divisão era a causa maior do fracasso da resistência histórica (...) ao colonialismo. O I Congresso é, pois, Congresso da UNIDADE (FRELIMO, 1977 apud LUIS, 2005, p. 24).

A agenda civilizatória da FRELIMO implicava forjar o "homem novo", nascido das tradições tribais, mas educado na luta pela libertação. O "homem novo" deveria ser o avatar de um novo tempo, no qual ciência, nacionalismo e comunitarismo iriam guiar a prática política e social. Contudo, o ambiente de guerra civil gerou um espiral de suspeitas no qual as divergências tendiam a ser interpretadas como traição à luta e afronta ao centralismo implantado na gestão da revolução em curso.

Na ótica de Coelho (2019), os congressos da FRELIMO deram luz ao chamado "Roteiro da Libertação" que explicita o trajeto do empreendimento nacionalista que produziu a independência moçambicana. A cada nova fase, uma nova crise, uma nova alternativa sempre tendo o nacionalismo como norte. Diante da irredutibilidade do colonizador, a alternativa básica da FRELIMO consistiu em agregar forças e caminhar para a luta armada. O enfrentamento do inimigo colonial não se deu sem ocasionar fraturas internas, donde emergiram cisões e novos agrupamentos. Cabe destacar que o $2^{\circ}$ Congresso da FRELIMO, ocorrido em 1968, marcou a prevalência do segmento pró-guerra popular e a revolução seguiu seu curso.

A ação dos populares foi marcada pela experiência revolucionária, em particular por meio da "narração de sofrimento", segundo a qual o ingressante das fileiras revolucionárias deveria descrever sua trajetória de luta. Além disso, eram enviados militantes de destaque com pouca vivência de campo de luta para regiões de conflito, a fim de adquirirem experiencia revolucionária - a teoria e a prática.

Sob a direção de Eduardo Mondlane, ocorreu o início do processo de luta armada em Moçambique. No entanto, Mondlane é assassinado, em 1969, por agentes da PIDE. Em seu lugar, é nomeado Samora Machel como o novo presidente da FRELIMO e 
será ele quem conduzirá com sucesso o processo de luta armada em Moçambique. Deve-se reconhecer que Samora Machel conseguiu criar uma amálgama de ideologia ancorada no marxismo-leninismo, a qual embasou a luta da FRELIMO.

\section{A luta armada em Moçambique}

Os primeiros pelotões de combatentes moçambicanos foram treinados na Argélia, no norte da África, onde tiveram apoio militar e ficaram mais próximos ideologicamente de outros países que alcançaram a sua independência através da luta armada de libertação nacional. Convém registrar que a Argélia obteve a sua independência da França em 1962, portanto, servindo de exemplo e base para treinamento aos países que possuíam o mesmo intento. As operações da FRELIMO começaram no dia 25 de setembro de 1964, com o ataque a vários pontos administrativos e militares na província de Cabo Delgado. A força militar de combatentes moçambicanos, após o treinamento na Argélia, possuía um recuo estratégico na Tanzânia, que também servia como posto de treinamento - ou, melhor dizendo, na expressão dos moçambicanos, era um "Centro de Formação do Homem Novo" (VISENTINI, 2013, p. 361).

Destaca-se que, neste momento inicial da guerra, o efetivo de soldados portugueses era maior do que o moçambicano, tanto no quesito quantitativo de soldados quanto nos vultosos valores monetários em curso. Quanto ao efetivo da FRELIMO, no seu início, as operações tinham o seguinte número de combatentes: em 1964, a guerrilha contava com pouco mais de 250 homens contra 35.000 soldados portugueses; e em 1967, a FRELIMO já atingira 8.000 homens treinados contra um efetivo de aproximadamente 65.000 a 70.000 soldados portugueses (MONDLANE, 1995). Porém, mesmo quantitativamente superior, Portugal apresentava vários problemas, principalmente nos seguintes aspectos: 1) como era de se esperar, em um processo conflitivo entre colônia e metrópole, a população de Moçambique era majoritariamente hostil aos portugueses; 2) quanto ao efetivo das forças militares, a FRELIMO, mesmo minoritária, era composta por moçambicanos 
que conheciam bem o seu próprio terreno, enquanto os portugueses eram estrangeiros lutando em território desconhecido; e 3) a luta empreendida em Moçambique, assim como em outras colônias portuguesas (como Angola), tornava-se mais um problema interno para o governo de Portugal na própria metrópole (VISENTINI, 2013).

Quanto a esta última questão, o desgaste se dava visto que ocorriam despesas excessivas e, consequentemente, faltava o apoio necessário da população metropolitana, principalmente em face da desgastada ditadura Salazarista. A fim de evitar maiores fissuras na metrópole e com o intuito de minimizar os conflitos reais insurgidos no continente africano, Salazar procurava minorar o conflito: reiteradamente negava-o, visto que desqualificava a luta como um simples processo de restabelecimento da ordem (CABAÇO, 2007)

Portugal possuía um exército tradicional, porém a FRELIMO, com muito esforço, possuía um exército irregular e apresentava combates de guerrilha aos moldes dos instrumentalizados na Argélia: a frente atacava o inimigo e o fustigava para, posteriormente, recuar estrategicamente em um local seguro na Tanzânia. Justamente por estar dentro do seu próprio território, a FRELIMO contava com um fator importantíssimo, que era o tempo empreendido na luta. A possibilidade de dispender tempo era vista de forma muito diferente por Portugal, cujos combatentes urgiam ter sucesso na empreitada militar, precisamente para evitar desmoralização, gastos e não ter reflexos de oposição dentro da metrópole, bem como para evitar que se propagasse que estava acontecendo uma revolução na África (VISENTINI, 2013). Aproveitando desse imbróglio português, a FRELIMO se utilizava do conhecimento da região e especialmente da identidade étnica da população para fomentar ainda mais o sentimento de natividade. A partir desse sentimento de pertencimento étnico, conseguiam o sucesso de aumentar o seu exército guerrilheiro. Neste sentido, o tempo e o sucesso das empreitadas contavam a favor da guerrilha, visto que iam adensando paulatinamente o seu exército - atacavam o inimigo e recuavam. 
De acordo com Cabaço (2007), existia uma dinâmica intrínseca entre o tempo e o espaço físico na guerra de libertação de Moçambique. Quanto mais o tempo se prolongava, proveitosamente, mais espaço conquistavam e ampliavam em favor da guerrilha, conquistando paulatinamente território e apoio local nativo. Quanto às tropas portuguesas, desembarcavam no conflito motivadas pela missão de debelar uma insurreição fomentada pela metrópole no continente africano; contudo, com o passar do tempo e o esgotamento das forças, os soldados mostravam-se cada vez mais ansiosos para atingir os dois anos necessários de prestação de serviço militar e, assim, de pronto poderem regressar às suas vidas na metrópole (CABAÇO, 2007).

Politicamente a direção da FRELIMO adotava a concepção de Guerra Popular Prolongada. Muito difundida no período por Mao Tse Tung, a partir do sucesso Revolução Comunista em 1949, essa concepção de guerra serviu, consequentemente, como exemplo aos demais países nos seus respectivos processos de libertação nacional (HOBSBAWN, 2008). Nesse modelo, além de visar a vitória no seu próprio espaço físico, locus em que os nativos são os reais proprietários do terreno, a FRELIMO também se dedicava a transmitir esclarecimentos sobre ideias e consciência de classe aos camponeses, a fim de conquistar definitivamente a população para o projeto da luta armada. Objetivamente, a aplicação do modelo de tática-estratégica da Guerra Popular Prolongada pressupunha intenso trabalho político e de organização entre as massas, bem como implicava a necessidade de organizar as forças armadas do povo, a partir de pequenos núcleos de combatentes, no amplo emprego da tática de guerrilhas e na criação de bases de apoio no campo.

A fim de conter a guerra em curso e minimizar o tempo, com vistas à solução efetiva do conflito, os portugueses deram ênfase para a construção dos aldeamentos, cujos objetivos eram confinar e manter sob controle os nativos. Para tanto, eles eram retirados de suas casas e aldeias, sem a sua consulta prévia. Convém registrar que os portugueses tentavam reproduzir ipsis litteris o modelo americano na luta do Vietnã (VISENTINI, 2013). Esta estratégia militar de deslocamento das populações das áreas de conflito 
possuía o seguinte argumento, na visão do exército colonial português: evitar o contato com os guerrilheiros, que a população local alimentava e para quem propiciava campo de recrutamento. Ainda, visando abrandar os ânimos dos moçambicanos e com o intuito de cooptá-los, insistiam que os aldeamentos eram com vistas a proteger a população e a criar polos de desenvolvimento socioeconômico, a despeito da guerra que se desenrolava, sem recuo e com o franco apoio da população à FRELIMO (CABAÇO, 2007).

Com o assassinato de Eduardo Mondlane, em 1969, o exército português possuía a expectativa de conseguir uma ação efetiva contra a guerrilha. No imediato ao assassinato, o exército português desencadeou a operação denominada "Nó Górdio", que objetivamente consistia em liquidar em definitivo a FRELIMO. No entanto, a ação foi um fracasso. Motivados principalmente pela revolta com a morte de Mondlane, novas regiões eram conquistadas e cooptadas para a guerrilha (LUIS, 2005). Desta forma, à medida que a FRELIMO ia conquistando paulatinamente mais espaço, ela adquiria apoio da população, revigorando, portanto, os ânimos guerrilheiros e criando verdadeiras zonas libertadas.

Embora ocorresse sucesso real da guerrilha em face das suas vitórias, os grupos internos que se aglutinaram taticamente para construir a frente de libertação começaram a apresentar fissuras internas de ordem programática e teórica no curso da luta, principalmente no tocante aos objetivos fins: concepção da linha política. Nesse percurso, se dividiam entre a linha revolucionário socialista de libertação nacional e a linha reacionária moderada, que também seria de libertação, mas que não queria mudanças no modelo de produção capitalista que vigoraria no país. No embate de ideias:

Os revolucionários argumentavam que a produção dos bens alimentares, para além do que os camponeses necessitavam para a sua própria sobrevivência, devia ser coletiva [...]. As forças moderadas eram da opinião que nas zonas libertadas devia haver um sistema comercial privado, que comprasse os excedentes dos camponeses em troca de bens de consumo (ABRAHAMSSON; NILSSON, 1994, p. 33). 
Embora houvesse rusgas evidentes no percurso da luta, a FRELIMO seguia as diretrizes do modelo marxista e de treinamento guerrilheiro com apoio, ora discreto, ora ostensivo, de países do bloco socialista. Portanto, a linha política revolucionária foi conquistando o seu espaço no seio da organização armada e, consequentemente, acomodando-se como concepção política durante o processo de independência nacional a posteriori. Contudo, deve-se registrar que esses processos não foram uma acomodação natural; pelo contrário, no curso político, realçaram-se inúmeras fissuras que dariam origem, posteriormente, a conflitos internos de grave caráter para a condução do processo revolucionário dentro de Moçambique.

Ainda assim, o curso da luta seguia positivamente para o lado das forças revolucionárias, especialmente com o adoecimento e morte de Salazar em 1970. Posteriormente, ocorreu um processo muito ruidoso de transição de poder em Portugal, gerando desgastes militares até a completa asfixia do governo, findada com a Revolução dos Cravos, em 25 de abril de 1974. Portanto, a partir daquele momento, a conjuntura mudou definitivamente a favor dos rebeldes moçambicanos, visto que, com a Revolução dos Cravos, liquidou-se totalmente o aparato da estrutura da velha e ultrapassada ditadura salazarista. Ou seja, naquele momento, a FRELIMO equilibrava-se entre a fortuna e a virtú (MAQUIAVEL, 1973): de um lado, contava com a sorte do falecimento do ditador e do avanço da revolução libertadora e, de outro, tinha um efetivo militar guerrilheiro muito bem consolidado e reconhecido no território nacional.

Logo, a revolução que modificou a sociedade portuguesa foi, igualmente, o alicerce seguro e dinamizador da transição para a independência de Moçambique. Em 07 de Setembro de 1974, houve o Acordo de Lusaka, na Zâmbia, o qual preparou o governo de transição. O presidente português, primeiro após a Revolução dos Cravos, ainda queria fazer uma transição lenta e gradual, de modo que se construísse em Moçambique as bases para o pluripartidarismo e se estruturassem as eleições, com vistas a definirem os futuros governantes moçambicanos (VISENTINI, 2013). Aproveitando-se da situação vulnerável do colonizador no período 
pós Revolução dos Cravos, em 1975, a FRELIMO logrou tomar o poder em Moçambique e alcançar a estabilidade política e econômica seria o grande desafio ao novo governo. A agenda política era descontruir o Estado colonial e substituí-lo por um genuíno Estado moçambicano, nascido das bases populares, com forte influência campesina.

Como as forças da FRELIMO já se encontravam amadurecidas depois de décadas de luta, elas forçaram uma independência definitiva, em 25 de julho de 1975, data do $13^{\circ}$ aniversário da FRELIMO. Os guerrilheiros saíram do front de batalha no interior e adentraram as principais cidades, tornando-se, portanto, a nova força efetiva do comando moçambicano. Samora Machel acertou em apostar no sucesso do avanço da luta armada, visto que, por volta de 1973, as forças nacionalistas já sobrepujavam a capacidade militar colonial. A independência moçambicana se tornou questão de tempo e Machel tornou-se o presidente de Moçambique, após a sua independência de Portugal, em 1975. A partir daquele momento, internacionalmente Moçambique fora considerado um país soberano; no entanto, adversidades advindas do período de descolonização e guerra apresentariam, após a independência, novos dilemas e desafios que iriam fragilizar ainda mais o nascente país.

\section{A construção do Estado-nação e o surgimento do homem novo}

Conforme explicitado, no processo de consolidação da independência moçambicana emergiu a figura de Samora Machel como o grande dirigente e porta-voz da nação. Neste bastião, uma de suas grandes tarefas era a formulação das diretrizes da educação, que tinha o intuito de forjar o "novo homem" da luta e do ideal socialista. Portanto, a educação seria uma das novas batalhas ideológicas da nova nação. Ademais, deve-se relembrar que o país não possuía uma unidade étnica nem linguística. Justamente por esse motivo, o idioma português foi escolhido como a língua oficial e, mesmo a despeito de várias rusgas, fora escolhido com o intuito de não acirrar disputas entre os diversos grupos linguísticos - a ideia 
não seria se submeter simplesmente à língua dos dominadores, mas gerar, a partir dela, uma nova unidade através da linguagem.

A forja de um pertencimento étnico-identitário seria mais complicada, haja vista que não havia um grupo tribal único. Portanto, havia a necessidade de "criar" o novo homem moçambicano e, com isto, o sentimento nacional de pertencimento a este nascente Estado-nação: “Unir todos os moçambicanos, para além das tradições e línguas diversas requer que na nossa consciência morra tribo a para que nasça a Nação" (MACHEL, 1978 apud MACAGNO, 2009, p. 21). Essa tarefa era extremamente hercúlea, uma vez que a criação dos tracejados territoriais moçambicanos fora fruto da partilha da África no século XIX (HOBSBAWN, 2016) e não da vontade das tribos nativas. Ou seja, além de terem que conviver em um território modelado pelos portugueses através dos acordos do século XIX, a despeito da vontade das tribos e das comunidades, ainda tinham que construir e ativar um sentimento de Estado-nação que não lhes era natural.

Nesse sentido, evidencia-se que a construção da nação moçambicana como uma entidade homogênea só seria compreensível sob a lógica do enfrentamento a outra entidade homogênea: a nação portuguesa. Assim, a construção da nação moçambicana dar-se-ia justamente para livrar essa nação definitivamente do seu passado colonial (MACGANO, 2009). Nesta perspectiva, essa nova nação deveria nascer a partir da forja desse novo homem, que seria educado dentro desta nova cultura e livre dos aspectos coloniais, de acordo com a seguinte fórmula: o novo Estadonação seria o produto da bricolagem, da junção das diferentes tribos tradicionais, desta vez em uma só nação - Moçambique, erigida pelo partido que comandava o Estado (FRELIMO). Esse partido forçava, sobremaneira, uma oposição à velha nação colonial portuguesa, já tornada uma esvanecida metrópole sem força, naquela quadra política.

Em 1977, no seu III Congresso, a FRELIMO aprofundou politicamente o seu referencial marxista e deixou definitivamente de ser uma frente ampla, transformando-se em partido e vindo a adotar o marxismo-leninismo como ideologia do seu projeto político, socioeconômico e cultural (GÓMEZ, 1999). Ou seja, o que antes 
era um agrupamento de guerrilha se converteu em um partido político de orientação marxista-leninista. O centralismo político e econômico foi marcante na forma de governar da FRELIMO, com a justificativa de que era necessário manter e promover a unidade moçambicana. Seguindo as diretrizes políticas em curso e como reflexo do modelo partidário regido pelo marxismo-leninismo, a FRELIMO tornou-se a organização máxima dirigente de Moçambique. Conforme modelo bolchevique de partido marxista, a organização político-partidária seria regida por um forte centralismo-democrático, sendo a figura máxima e o dirigente principal o próprio presidente do país, Samora Machel. Logo, a práxis marxista passaria a ser a viga mestra, tanto da política adotada quanto do ideal do novo homem a ser seguido. Também se deve salientar que a FRELIMO adquiria status de partido/Estado, de acordo com o mesmo modelo dos demais países que adotaram o marxismo-leninismo, após a II Guerra Mundial. Quanto aos princípios do marxismo de Samora Machel, ele declarou a um sociólogo como fora despertado para esta teoria política e práxis de luta:

"Bem", disse o Presidente, "quando era jovem costumava ajudar o meu pai, que era camponês". E, continuo descrevendo como os camponeses africanos recebiam preços muito mais baixos pelos seus produtos que os colonos portugueses, e falou das várias facetas da exploração que testemunhou em criança. Ziegler, começando a ficar impaciente, disse: "Sim, senhor Presidente, mas quando leu Marx pela primeira vez?" "Bem", disse Samora, "mais tarde na vida juntei à FRELIMO e tomei parte na luta armada". E continuou falando dos conflitos políticos dentro do movimento, como a história de Ncavandame e dos novos exploradores. Não querendo ser metido no bolso com esta evasiva bem clara, o sociólogo insistiu; "sim, sim, mas ainda não me disse quando foi a primeira vez que leu Marx": "Ah, isso", disse Samora. "durante a luta de libertação alguém me deu um livro de Marx. À medida que o lia, apercebi-me que estava a ler Marx pela segunda vez (CHRISTIE, 1996 apud MACAGNO, 2009, p. 24). 
Desta forma, o grande porta-voz Samora era o exemplo vivo deste novo homem, assim como foram os outros dirigentes políticos marxistas que ascenderam nas lutas dos processos de libertação nacional, a exemplo de Mao Tse Tung na Revolução Comunista chinesa. Em outras palavras, a partir do exemplo de Machel, a forja do homem novo seria na luta, lado a lado com a população camponesa. O guerrilheiro e camarada daria luz à construção do homem novo e adquiriria a consciência de sua nova condição de classe, vindo, consequentemente, a se libertar do jugo colonial. Deste modo, nesta construção do homem novo, o arcaico e o tradicional deveriam ser erodidos e não somente a ultrapassada estrutura colonial portuguesa, mas também a tribo tradicional, símbolo da ignorância, do atraso e da falta de consciência com a modernidade. Portanto, as falas de Samora Machel e o projeto político da FRELIMO possuíam raízes profundas na forma como se estabelecera a luta de libertação, bem como as suas concepções políticas e, principalmente, o modelo teórico inspirado no marxismo-leninismo.

Nesse sentido, no plano econômico, os dirigentes da FRELIMO investiram seus esforços na agricultura, em consonância com o caráter pedagógico da construção do homem novo. Essa construção tinha como linhas 1) as machambas estatais, que deveriam produzir bens de exportação e cobrir uma grande parte da necessidade total de bem alimentares, e 2) as aldeias comunais, que consistiam em fomentar as famílias a viverem em aldeias coletivas, a fim de melhorar a sua qualidade de vida (ABRAHAMSSOM; NILSSON, 1994).

Porém, essa nova nação engendrada por esse novo homem seria um locus de constante disputa, gerando, posteriormente, severos conflitos no território moçambicano. Melhor explicando, nesse novo modelo pedagógico, o dirigente máximo Samora Machel possuiria mais de uma frente de luta a combater: 1) primeiramente, os seus inimigos internos; e, 2) posteriormente, tão gravoso quanto, os seus inimigos externos. Quanto aos primeiros, registrou-se que eram os moçambicanos que não estavam enquadrados no ideal disciplinar e moralizador imposto pela FRELIMO. Para fins de propaganda, chegaram a criar o Xiconhoca, um 
personagem que representava o paradigma do bêbado, corrupto e explorador, em síntese, a antípoda do homem novo moçambicano socialista (MACAGNO, 2009).

No plano externo, o inimigo era bem mais deletério: tratava-se dos contrarrevolucionários da nascente Resistência Nacional de Moçambique (RENAMO). Neste cenário, no imediato ao processo de independência, Moçambique passou a apoiar os processos nacionalistas na Rodésia e a criticar o racismo da África do Sul; como consequência veio a sofrer represálias dos seus vizinhos, bem como ainda havia os moçambicanos de origem portuguesa que se refugiaram na África do Sul e que tinham o objetivo de desestabilizar o governo socialista de Moçambique.

Após o III Congresso da FRELIMO e com a adoção do marxismo-leninismo, Moçambique solicitou o apoio formal da União das Repúblicas Socialistas Soviéticas (URSS), com vistas a integrar o bloco comunista que fazia parte do Conselho para Assistência Econômica Mútua (COMECON). Porém, com isto, perderam o apoio chinês e norte-coreano ao seu país, ainda um reflexo do conflito sino-soviético dos anos 1960. ${ }^{1}$ Samora Machel estava querendo construir a nação e o novo homem em um terreno extremamente conflitivo, o que ainda pesaria desastrosamente contra Moçambique.

Portanto, nesta perspectiva e seguindo o pensamento do dirigente, pode-se considerar que a independência completa de Moçambique somente se processaria com a extirpação do velho colonialismo e a construção do novo homem, socialista e moderno. No entanto, o sonho foi além das condições objetivas e do alcance de Moçambique, pois o novo Estado-nação precisava lutar contra um inimigo infinitamente superior à antiga metrópole lusitana: os Estados Unidos. Segundo Abrahamssom e Nilson (1994), o projeto socialista de Moçambique foi encarado pelos Estados Unidos como uma afronta. Como consequência desta disputa de

\footnotetext{
1 No tocante ao conflito sino-soviético e para a compressão dos seu reflexos nos alinhamentos a posteriori, o marxismo internacional cindiu-se entre os dois países - União Soviética e China - em meados da década de 1960, em linhas gerais, pelos seguintes motivos: 1) discussões acerca do caráter excessivamente pacifista da União Soviética; 2) divergência sobre a questão dos mísseis em Cuba; 3) fim da ajuda econômica da URSS à China e 4) críticas, por parte da China, sobre a exposição exagerada dos crimes de Stalin (CHILCOTE, 1982).
} 
forças, uma nova luta começaria a ser forjada em Moçambique: FRELIMO versus RENAMO, esta última com o apoio da Rodésia, África do Sul e Estados Unidos. Esta luta vai levando paulatinamente o país ao soterramento, até a sua completa derrocada na década de 1980, quando figura em um nível de pobreza altíssimo. Justamente em consequência desta luta, haverá também o esgotamento do projeto revolucionário pedagógico do novo homem forjado pela FRELIMO, bem como o desgaste do seu partido e, por conseguinte, a erosão do projeto comunista no final do percurso revolucionário.

A tentativa de construção do novo modelo de Estado, igualmente com o intuito de buscar o homem novo de acordo com os ideais do marxismo-leninismo, acarretou em profundas divergências internas no próprio país, outrora já acentuadas pelo colonialismo. De acordo com esse novo modelo marxista erigido sem o amplo consenso popular, extirparam os modelos de comunas tribais, do mesmo modo alijaram o poderio de grupos e líderes tradicionais, posto que somente ascendiam no governo as lideranças da FRELIMO, através do partido. Com isto, avivaram rusgas e conflitos, o que acabou por apoiar os rebeldes contrarrevolucionários da RENAMO, dispostos a restaurar outro modelo político-econômico baseado no capitalismo, haja vista que contavam com apoio dos Estados Unidos e da África do Sul.

Além desses condicionantes geopolíticos que erodiam forte e militarmente o país, a URSS começava a esvair o seu apoio, principalmente em função das crises da Guerra Fria, na década de 1980, e da Perestroika liderada por Mikhail Gorbachev, anos depois. Assim, Moçambique foi perdendo os apoios internacionais, sendo invadida pela RENAMO a partir dos seus vizinhos, que davam sustentação econômica e militar aos contrarrevolucionários. Pesaria com grande gravidade a crise política e uma seca devastadora em 1984, que veio a arrasar a produção agrícola do país, trazendo severos dissabores. Consequentemente, houve o esgotamento do modelo proposto pela FRELIMO por exaustão, conflitos internos, contrarrevolução, pressões internacionais e fim da ajuda do bloco socialista (VISENTINI, 2013). 


\section{Considerações finais}

O processo de libertação de Moçambique da metrópole portuguesa foi lento e extremamente belicoso, tendo perdurado de 1962 a 1975. No entanto, conforme exposto, o tempo estava a favor dos moçambicanos nacionalistas que lutavam em seu próprio terreno e ganhavam novos adeptos com o desenvolvimento da insurreição armada. De um início tímido e modesto, a luta armada eclodiu em um processo de transformação ideologicamente ousado: o nascimento do "novo homem". Como se não bastasse criarem uma nação, os moçambicanos ainda possuíam a pretensão de construir um Estado-nação socialista, edificando o novo e educando o povo na luta diária contra os antigos sistemas tribal e colonial, que tinham outrora lhes aprisionado.

Grosso modo, a luta era construir uma nova sociedade, um novo Moçambique, sepultando de vez todas as formas de dominação da antiga colônia portuguesa. Neste processo, os dirigentes moçambicanos buscavam, através dos paradigmas socialistas, adequar os seus discursos revolucionários e construir uma economia voltada para a coletividade. Porém, o poder de fogo do inimigo interno e externo fora devastador ao sonho moçambicano de construção do novo homem. No imediato à independência, em 1975, começou a reorganização de forças contrárias à direção da FRELIMO e a constituição formal da RENAMO, que contava com apoio internacional e forte poderio econômico.

A RENAMO tornou-se o maior entrave para a consecução política das diretrizes adotadas pela FRELIMO: dinamitavam pontes, incendiavam plantações, assassinavam apoiadores do governo, ou seja, faziam terrorismo ao Estado moçambicano. Ao mesmo tempo em que lutavam contra a FRELIMO, as forças contrarrevolucionárias contavam com a ajuda dos chefes das tribos tradicionais, que foram alijados do poder pelo novo governo moçambicano, bem como com auxílio dos chefes de instituições religiosas desprezadas pelo corolário do marxismo-leninismo. Com esta contraofensiva, conseguiam conquistar zonas de dominação, no desenrolar da luta.

O processo foi tão violento que a RENAMO pôs em xeque o poder do partido único da FRELIMO. Após a quase destruição do 
país, no início da década de 1990, estabeleceram um cessar fogo e, no imediato, houve as primeiras eleições para presidente com disputa das duas forças políticas: novamente FRELIMO versus RENAMO em confronto. Contudo, dessa vez, a disputa se deu nas urnas e de forma pacífica, com a vitória da FRELIMO. Finalizando, pode-se dizer que, de 1962 ao início dos anos 1990, a tentativa da construção do "homem novo" e do ideário socialista fora totalmente sepultada, pois o que restou foi um saldo deletério de muitos mortos: o país foi dizimado por uma guerra civil e Moçambique encontra-se atualmente no ranking dos países com menor índice de desenvolvimento humano do mundo (RANKING..., 2014).

\section{Referências}

ABRAHAMSSON, H.; NILSSON, A. Moçambique em Transição: um estudo de história de desenvolvimento durante o período 1974 - 1992. Maputo: CEGRAF, 1994.

CABAÇO, J. L. de O. Moçambique: identidades, colonialismo e libertação. 2007. Tese (Doutorado em Antropologia Social) - Programa de PósGraduação em Antropologia Social, Universidade de São Paulo, São Paulo, 2007.

CHILCOTE, R. H. O partido comunista brasileiro: conflito e integração. Rio de Janeiro: Graal, 1982.

COELHO, J. P. B. Política e história contemporânea em Moçambique: dez notas epistemológicas. Revista História (São Paulo), São Paulo, n. 178, p. $01-19,2019$.

COMITINI, C. Amilcar Cabral: a arma da teoria. Rio de janeiro: CODECRI, 1980.

FRANCO, P. F. C. Amilcar Cabral: a palavra falada e a palavra vivida. 2009. Dissertação (Mestrado em Histórica Social) - Programa de Pós-Graduação em História Social, Universidade de São Paulo, São Paulo, 2009.

GÓMEZ, M. B. Educação Moçambicana - História de um Processo: 1962-1982. Maputo: Livraria Universitária, 1999.

HOBSBAWN, E. A era dos extremos: o breve século XX. São Paulo: Companhia das Letras, 2008. 2016.

A era dos impérios: 1875-1914. 22. ed. São Paulo: Paz e Terra, 
LUIS, A. J. Políticas do banco mundial para a educação básica moçambicana - 1985 - 2000. 2005. Dissertação (Mestrado em Educação) - Programa de Pós-Graduação em Educação, Universidade Federal de Santa Catarina, Florianopólis, 2005.

MACAGNO, L. Fragmentos de uma imaginação nacional. Revista Brasileira de Ciências Sociais, São Paulo, v. 24, n. 70, p. 18 - 35, 2009.

MAMIGONIAN, B. G. José Majojo e Francisco Moçambique, marinheiros das rotas atlânticas: notas sobre a reconstituição de trajetórias da era da abolição. Topoi, Rio de Janeiro, v. 11, n. 20, p. 75 - 91, 2010.

MAQUIAVEL, N. O príncipe: escritos políticos. São Paulo: Abril Cultural, 1973.

MONDLANE, E. Lutar por Moçambique. Maputo: [s.n.], 1995.

PEIXOTO, C. B. T.; MENESES, M. P. Domingos Arouca: um percurso de militância nacionalista em Moçambique. Topoi, Rio de Janeiro, v. 14, n. 26, p. $86-104,2013$.

PEREIRA, M. S. Batuques negros, ouvidos brancos: colonialismo e homogeneização de práticas socioculturais do sul de Moçambique (18901940). Revista Brasileira de História, São Paulo, v. 39, n. 80, p. 155 177, 2019.

RANKING IDH Global. PNUD Brasil, [online], 2014. Disponível em: $<$ https://www.br.undp.org/content/brazil/pt/home/idh0/rankings/idhglobal.html>. Acesso em: 13 fev. 2020.

RIBEIRO, L. D. T. Descolonização da África e da Ásia. Ciências \& Letras, Porto Alegre, n. 33, p. $53-86,2003$.

THOMAZ, F. N. Disciplinar o "indígena" com pena de trabalho: políticas coloniais portuguesas em Moçambique. Estudos históricos, Rio de Janeiro, v. 25, n. 50, p. 313 - 330, 2012.

VISENTINI, P. G. F. Revolução e regimes marxistas: rupturas, experiências e impactos internacionais. Porto Alegre: Leitura XXI; UFRGS/ NERINT, 2013. 